Mercator, Fortaleza, v. 16, e16004, 2017.

DOI: https://doi.org/10.4215/rm2017.e16004

ISSN: $1984-2201$

Copyright @ 2002, Universidade Federal do Ceará

\title{
MARITIME VILEGIATURE AS VECTOR OF BRAZILIAN URBANIZATION
}

\author{
GOMES, Iara Rafaela ${ }^{*}$
}

(a) Doutora em Geografia. Prof $f^{a}$ da Universidade Federal do Ceará (UFC). http://lattes.cnpq.br/0898182484894997

\section{(*) CORRESPONDING AUTHOR}

Address: U/F/C, Departamento de Geografia - Campus do Pici, CEP: 60440900, Fortaleza (CE), Brasil. Tel: (+55 85) 33669855 E-mail: iarageo@gmail.com

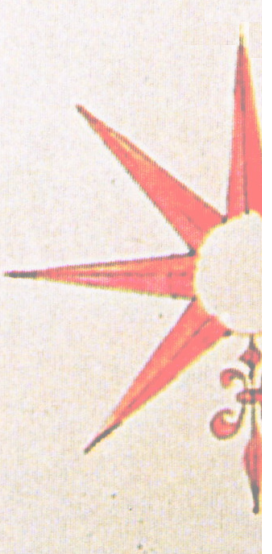

9

The logic of the urbanization of coastal areas can be associated with maritime vacationing, whose growth rates in the last decade have been intense and have become fundamental in implementing the leisure practices of the populations of large and medium-sized conurbations. To understand this dynamic, we analyze the expansion of this practice in the coastal area of Tibau, a small city that is part of the area of influence of Mossoró, the second most important and populous city of Rio Grande do Norte, Brazil. Understanding Mossoró's influence on the expansion of maritime vacationing in Tibau shows how the coastal space is reached by the city's urban fabric and, above all, how the non-metropolitan cities redefine a logic that, at first, was controlled by the metropolises. In this sense, we treat the growing demand for recreational areas, particularly coastal ones, as responsible for redefining urbanization and the consequent establishment of a more complex urban network.

Keywords: Second residence; Coastal urbanization; Mossoró; Tibau; Modern maritime practices.

\section{RESUMO/ RESUMEN}

\author{
VILEGIATURA MARÍTIMA COMO VETOR DA URBANIZAÇÃO BRASILEIRA
}

A lógica de urbanização dos espaços litorâneos pode ser associada à vilegiatura marítima, cujos índices de crescimento na última década são intensos e se torna fundante na implementação de práticas de lazer das populações das grandes e médias aglomerações urbanas. Para compreender esta dinâmica, analisamos a expansão desta prática no espaço litorâneo de Tibau, cidade de pequeno porte que compõe a região de influência de Mossoró, segunda cidade mais importante e populosa do Rio Grande do Norte, Brasil. A compreensão da influência de Mossoró na expansão da vilegiatura marítima em Tibau revela como o espaço litorâneo é alcançado pelo tecido urbano daquela cidade e, sobretudo, como as cidades não metropolitanas redefinem lógicas que, à princípio, eram comandadas pelas metrópoles. Neste sentido, tratamos a crescente demanda por espaços de lazer, particularmente litorâneos, como redefinidora da urbanização e consequente estabelecimento de uma rede urbana mais complexa.

Palavras-chave: segunda residência; urbanização litorânea; Mossoró; Tibau; Práticas marítimas modernas

\section{VILEGIATURA MARÍTIMA COMO VECTOR DE LA URBANIZACIÓN}

La lógica de la urbanización de las zonas costeras pueden estar asociados con las vacaciones mar, cuyas tasas de crecimiento en la última década son intensas y se convierte en la fundación en la ejecución de las prácticas de ocio de las poblaciones de grandes y medianas ciudades. Para comprender esta dinámica, analizamos la expansión de esta práctica en la zona costera de Tibau, ciudad de pequeñas empresas que conforman la región de influencia de Mossoró, segunda ciudad más importante y poblada de Rio Grande do Norte, Brasil. El conocimiento de la influencia de la expansión de los mares de vacaciones en Tibau revela cómo la Unión ruta costera es alcanzado por el tejido urbano de la ciudad y, especialmente, como las ciudades no metropolitanos redefinm lógico que, en un primer momento, fueron controlados por las metrópolis. En este sentido, tratamos a la creciente demanda de áreas de esparcimiento, especialmente del litoral, como redefinidora de urbanización y el consiguiente establecimiento de una red urbana más compleja.

Palabras clave: Segunda residencia; Urbanización costera; Mossoro; Tibau; Prácticas marítimas modernas. 


\section{INTRODUCTION}

This text seeks to reflect on the new trends and orientations of Brazilian urbanization. The idea is to encourage the perception of today's Brazil according to the new variables that are emerging as vectors of this process, including maritime vacationing. The urbanization process in the present historical period is complex and is associated with several causes, such as cultural and historical heritage and sensitivity to the demands of economic, political and territorial modernization. This means that the results differ from one continent to another and even within their respective countries. It is essential to verify recent trends in urbanization at this time and reflect on the new vectors that shape it in Brazil.

For example, it is possible to identify several areas where urbanization is directly attributable to the practice of maritime vacationing. In several areas of the country's vast coastline cities have developed whose main function is clearly associated with the demands of the dynamics linked to vacationing. Effectively it is part of a broader reality that has been observed by several authors worldwide, although studies are still relatively scarce and certainly require a huge research agenda.

The modern maritimity ${ }^{1}$ associated with the urban core brings with it the need to understand the occupation of the seashore in capital cities and subsequently the rest of the metropolitan coastline (PEREIRA, 2014). However, it is not only this coastal area that embodies this reality, since it also establishes itself in other possibilities and scales, in addition to vacationing itself, which has been in force in other not necessarily metropolitan areas.

In general, several processes have spread and increased urbanization. Some examples are the articulations and forces of different political groups, the expansion of the tertiary sector, and the attraction of major industries. Thus, the urbanization that arises from the spread of modern maritime practices has seldom been dealt with.

The urbanization parallel to the coastline comes from the spread of the appreciation of the coast and has been quite evident as a process closely linked to leisure activities associated with the sea and the maritime and which is studied and presented from different views, possibilities and terminologies. Like any process, urbanization and its relationship with vacationing or even residential tourism ${ }^{2}$ can only be understood in the context of a convergence of factors, which meet in time and space.

With regard to the academic approach to the issue of vacationing as a form of leisure and its materialization in homes, the 1980s and 1990s are remarkable in Brazil for the works of Seabra (1979), Tulik (1995), and Roque (1990), who addressed the issue using case studies of regions where there has been rapid growth of this type of phenomenon. Examples include the Spanish and Portuguese coasts, the French and Swiss mountains, as well as tourist sites in the Asian, African and American continents. The articles address the socio-spatial issues of tourism and second homes in these locations and may be relevant sources for studies on the issue.

Countries like Spain have been studying the phenomenon for some years. In Brazil, authors such as Benhamou (1971), Coelho (1986), Tulik (1995), Assis (2003), and Pereira (2010), among others, discuss this issue from different perspectives. For Assisi (2003), a second home is a spatial form linked to weekend tourism or the vacation season and is determined by a set of social, economic and spatial factors that add complexity to the issue, such as the availability of free time, surplus income and the distance from the permanent residence.

In Brazil, this phenomenon has occurred as a socio-spatial fact, characteristic of contemporary society, especially from the 1950s. By increasing the urbanization process, the second home has

1 To Claval (1996), maritimity corresponds to a phenomenon experienced by a society whose borders are not very precise. This can be understood, in a simple manner, as the set of relationships that a population establishes with the sea from dimensions like preferences, images and collective representations.

2 For further reading on residential tourism, we suggest the following authors: Benhamou (1971); Delgado (2008); HiernauxNicolas (2005); Hall and Müller (2004); Nieves Terán and Martínez (2008). 
emerged as one of the socio-spatial practices that transform and redefine the relationship between cities in a territory, because the urban process is configured in a constant trajectory, searching for spaces with social and environmental amenities, with the potential for the practice of vacationing.

In the case of Brazil, there really is no relevant tradition of Metropolitan case studies. Authors such as Dantas $(2008,2009,2010)$ and Pereira $(2006,2009,2012)$ have been expanding the discussion on this issue for several years. However, considering the importance given to the coastal zone and the dynamics that reshape it these days, we intend to demonstrate the existence of a relationship between the process of urbanization and maritime vacationing, which does not only take place in metropolitan areas. Initially there is a brief reflection on the increase in dwellings for occasional use and therefore maritime vacationing in Brazil and worldwide. After this, we will analyze the relationship between vacationing and increasing urbanization in non-metropolitan areas, bringing to light the Brazilian empirical case.

\section{ANALYSIS OF BRAZIL AND THE WORLD}

The construction and sale of dwellings for occasional use $\mathrm{e}^{3}$ is one of the main types of leisure that flourished in many countries from the second half of the twentieth century onward. In the past, the main characteristic behind people's interest in enjoying a second home was its relative proximity to their primary residence for recreational purposes during the weekends or extended vacations. Nowadays, this modality transcends the borders between countries or even continents.

From the second half of the twentieth century, the great interest of private capital and the public sector strengthened this activity, especially in terms of its economic return and the presence of an extensive market interested in the product, especially European retirees, and the expansion of low-cost flights. Similarly, it is noteworthy that the expansion of this phenomenon was accompanied in many places by a process of intense social change and various socio-spatial impacts.

At a global level, it is noteworthy that after World War II and for more than half a century, Europe experienced a period of relative prosperity. In this context, various forms of tourism and the rise of maritime vacationing were established. It is significant that since the turn of the twentieth century and in the twenty-first century, baby boomers acquired houses to spend their free vacation time, in anticipation of the restoration guaranteed by the Welfare State. It is also worth highlighting the lifestyle of the new generations that redefined itself through a logic of abundance etc. (BRITO, 2010)

Brito (2010) also points to other factors such as the deregulation of air transport in the European Union, which went beyond the constraints of seat only charter flights, increasing the amount of free use of air links and making trips to houses purchased as second homes cheaper. The development of ICT (information and communication technologies) in general, and the Internet in particular, encouraged the diversification of proposals for prices and services. Travel between northern Europe and the Mediterranean Basin, for example, began to undergo a transformation in its structure.

Starting with the modernization of the means of transport, the technical and scientific achievements of the last decades have decreased distances by time saved, making it possible for second homes to be increasingly distant from permanent homes. This premise is quite relevant to an understanding of the internationalization of the process of the demand for occasional use property in Brazil in recent years, despite the fact that national vacationers in particular still regard distance a significant variable when purchasing a property. ${ }^{4}$

3 This definition is much more technical and was established based on criteria that allowed counting properties that have common characteristics: a private property and seasonal use. (IBGE, 2003)

4 For data in this regard, see the publication of the Federal Government entitled "Tourists Market Foreigners Second Residence in Brazil", which can be accessed at: http://www.dadosefatos.turismo.gov.br/export/sites/default/dadosefatos/demanda_turistica/ segunda_residencia/downloads_segunda_residencia/segunda_residencia__relatorio__setembro_de_2008.pdf 
In the case of Europe however, it is pertinent that the first seaside resorts were emerging from the late eighteenth century, although not in an even and linear way. Nevertheless locations for vacationing appeared in many different contexts and with diverse characteristics, including the Coasts of Holland (Shevenigen), Belgium (Ostend), France (Boulogne, Dieppe, Biarritz), Portugal (Cascais and Estoril) and Spain (San Sebastian). (PEREIRA, 2012).

Although these contexts are separated by decades, it is worth stating that Spain is notable in various aspects of the issue of second home ownership by foreigners from central and northern Europe, who are seeking a mild climate and a better quality of life obtained because of the difference between the average income in their country of origin and Spain. (COLAS, 2003).

When the discussion moves to North America, we soon turn to the urbanization of the coast of Florida. A quick observation using simple software like Google Earth, enables a comparison with the largest and densest tourist areas of the Mediterranean or the traditional Côte d'Azur (the evolution of roads parallel to the coast, from the first "marginal" to the multi-lane highway is well-known). For example, one can observe the development of leisure activities over more than a century, in a country that has not had armed conflict or other crises within its territory

The well-known Highway 666 reaches the Pacific in Santa Monica, changing into the Santa Monica Boulevard. The urban continuum links the resort to the formerly distant Los Angeles, Malibu and the beginning of Sunset Boulevard. The prosperity of the entire Los Angeles area (and San Diego) is the origin of the transformation of Palm Springs. From the 1960s, what began as a zone of sanatoriums developed into what is perhaps one of the most equipped and wealthy destinations for tourism and leisure in the West. (BRITO, 2010).

As with other economic activities, the increase in vacationing has occurred in a sustained way, alternating cycles of limited growth with stagnation, there may be a decrease in the event of armed conflict or a historical crisis. Returning to the case of Europe, the 2008-2009 crisis seems to mark the separation between two periods in the history of European vacationing.

When we reflect on the relationship between Europe and Brazil, it is worth mentioning that in the mid-2000s, Europeans accounted for a third of the new real estate purchases in some states in the Brazilian northeast, such as Ceará and Rio Grande do Norte. ${ }^{5}$ However, with the slightly higher value of the real and real estate prices in Europe pressured by the crisis on that continent, Brazilians are beginning to go in the opposite direction. One of the decisive points when choosing the investment was and has been the European passport. With some types of programs, just one identification card allows freedom of movement in the space known as Schengen, ${ }^{6}$ which covers 26 European countries. Many of these schemes require that at least part of foreigners' investment be in real estate. This is an attempt to revive housing markets heavily hit by the crisis. However, the process is much more complex and dynamic than is supposed,

It is worth noting that the complexity of this process also occurs on other scales. While we recognize the importance of the phenomenon of maritime vacationing and second homes in metropolitan environments, this dynamic is also a process that does not only happen in this context. To discuss the relationship between vacationing and urbanization, several issues need to be examined.

$5 \quad$ For further reading on the subject, see the book Turismo e Imobiliário nas metrópoles (organized by the following authors: Eustógio Wanderley Correia Dantas Angela Lucia Ferreira and Maria do Livramento Miranda Clementino), especially Alexsandro Ferreira Cardoso da Silva's article "Estratégias dos investimentos estrangeiros no Nordeste."

6 "The Schengen area includes 26 European countries that have decided to remove all internal border controls, which means that citizens can move freely in that space without having to show their passports. This area is named after the town of Schengen in Luxembourg where the agreement establishing the European area without frontiers was signed. The Schengen countries have strict border controls for citizens crossing their external borders. There are 26 Schengen countries including 22 of the $28 \mathrm{EU}$ countries and 4 countries outside the EU: Austria, Belgium, Czech Republic, Denmark, Estonia, Finland, France, Germany, Greece, Hungary, Iceland, Italy, Latvia, Liechtenstein, Lithuania, Luxembourg, Malta, Netherlands, Norway, Poland, Portugal, Slovakia, Slovenia, Spain, and Sweden. (taken from the website - Immigration Portal of the European Union 08.04.2015 - http:// ec.europa.eu/immigration/preciso-de-visto/preciso-de-visto-de-curta -duracao_pt). 


\section{NON-METROPOLITAN SPACES AND MARITIME VACATIONING}

Globally, the urbanization process that has maritime vacationing as its main vector should address the diversity of the dynamics related to it. It is insufficient only to look for this explanation in the dynamism of the metropolises, especially when, despite the claims made regarding these metropolises, there is also growth in the relevance of a group of medium-sized cities, some of which have even become regional centers and important articulators in the territory.

Therefore, the process of urbanization is quite complex. In the current historical period it has various causes, such as historical and cultural heritage, as well as sensitivity to the demands of economic, political and territorial modernization, with different responses in the different continents and even within each country. On observing a country like Brazil, for example, with continental dimensions and a coastline of over $8500 \mathrm{~km},{ }^{7}$ which in the words of Milton Santos (2011, p. 226), "is one of its most striking features", this urbanization is an even more multiple phenomenon. Sometimes it starts on the coast and sometimes in the interior, subsequently modifying in accordance with diverse factors, favoring this scope and complexity. Therefore, nowadays there are new trends of urbanization, leading us to reflect on the new vectors that shape this process in Brazil.

As an important vector of the urbanization process, maritime vacationing is notable in the current analysis because due to historical factors associated with the occupation of the Brazilian territory and following the global trend for the population to predominantly occupy areas near the coast. The IBGE estimates that $26.6 \%$ of the Brazilian population lives in cities in the coastal zone; equivalent to 50.7 million inhabitants. Regarding the number of second homes in these areas, figure 1 below shows that a significant part of the population is engaged in activities directly or indirectly related to the production of oil and natural gas, fishing and the services related to the economic dynamics generated by these municipalities and others nearby, as well as tourism or maritime vacationing (IBGE, 2011).

The important role of commercial shipping in the integration of the Brazilian circuits of production and consumption in the world economy is clear. This consequently led to an uneven demographic distribution, favoring coastal areas, beyond the economic core.

In Brazil, the incorporation of beach areas occurred in a gradual way. From the point of view of symbolic values, the proximity itself (and later incorporation) of these areas was associated with what the sea represented. Man's relationship with the sea is quite remote. However, the way the coastal landscape is conceived has not always been the same. According to the copious documentation analyzed by Corbin (1989), for example, the sea has been the reason for fear and dread and in the early stages of the enjoyment of the coast, visits to these spaces were only for medicinal purposes and were segregated both from the point of view of gender and social classes.

In Brazil, the attraction of these places can be explained based on external factors, that is, linked with the new desire on the part of the European (and later American) elites for the empty spaces of beaches from the end of the eighteenth century. Brazilians discovered the sea as transformations took place in Western lifestyles. In this view, the tunnel ${ }^{8}$ built in Copacabana, Rio de

\footnotetext{
7 "The Brazilian coastal zone is 8698 kilometers long and has a variable width; it includes a group of contiguous ecosystems covering an area of approximately $388,000 \mathrm{~km}^{2}$. It includes an onshore area with a set of municipalities selected according to specific criteria and a marine area, which are the Brazilian territorial waters extending 12 nautical miles from the coastline “(GERCO - fully Text taken from the Ministry's website Environment, accessed November 2011 - HTTP: //WWW.mma.gov.br/ port/SMA/gerco/gerco.html).

8 O Alaor Silver Tunnel opened as Real Grandeza Tunnel, more popularly known today as Túnel Velho, is located in the city of Rio de Janeiro between the neighborhoods of Botafogo and Copacabana. Both the tunnel and the first tram line were inaugurated in 1892. The perforation of the Real Grandeza tunnel was promoted by the Ferro-Carril Company of the Botanical Garden, as part of a real estate strategy that, at the beginning of the Republic, intended to invest in the coastal region of Copacabana, promoting it as a new lifestyle in the city that intended to modernize. The difficult access to this stretch, isolated by hills, was overcome by opening to traffic, the same year the opening of the tunnel, of the first line to this neighborhood (CARDOSO, 1986).
} 


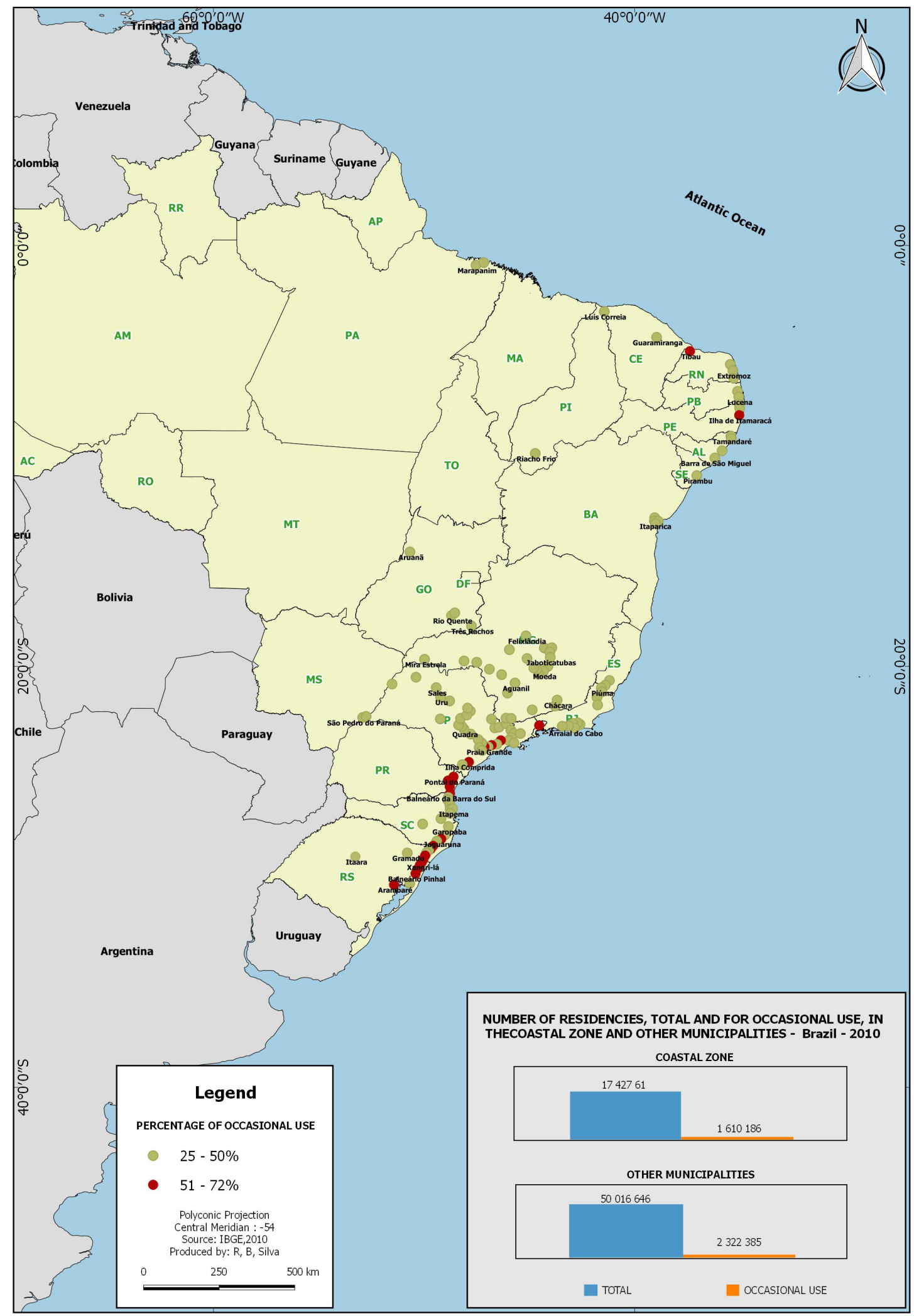

Figure 1 - 
Janeiro, in the late nineteenth century, may represent the beginning of such a process. Frequent visits to the Brazilian beaches in Rio de Janeiro, Salvador, Recife, Natal or Fortaleza only became a mass phenomenon in the postwar years.

One of the tools that accelerated this propagation of both people and ideas was certainly the airplane. The Brazilian population quickly appropriated such ideas. The comings and goings of people gave access to information and a variety of literature. At first, customs were similar to those of Europeans, that is, the beaches were frequented for health treatments. However, sea bathing was slow to arrive from Europe, first in the South and Southeastern Brazil and then more rapidly in other Brazilian beaches (DANTAS, 2009).

In Brazil, the aforementioned bathing was not as extensive as in the West. For Dantas (2004) and Dantas and Pereira (2010), this is probably because of the poor efficacy attributed to bathing by the local medical community, who mainly emphasized the positive aspects ascribed to the climate associated with the lavoisian theory of good respiration. Accordingly, Dantas and Pereira (2010) highlight that with the discovery of the beach areas by vacationers there was a slow change from the beginning of the twentieth century, of a picture of occasional, small-scale urbanization. ${ }^{9}$ Therefore, the arrival of vacationers conferred a new rationale to living on the beach, which previously was exclusively linked to trade or to native and poor populations.

As can be seen, the building of second homes on the coast is a relevant vector of urban expansion, both the spatial forms and the new social conditions. These forms, generally associated to the fixed, meet the recreational needs of metropolitan and non-metropolitan residents, as nowadays the appeal to the sea invades the imagination of people from the most diverse places, be they close to the coast or not. Thus, urban society creates stronger links with the coastal municipalities.

According to Dantas, Pereira and Panizza (2008) from the late 1980s to the present day, vacationing has intensified both by the increased infrastructure implanted for it (the foundation for the creation of tourism), and by having grown due to the utilization of infrastructural improvements imposed by tourism development policies in Brazil.

These policies deserve attention today, given the strong growth of maritime vacationing and tourism development policies in the late twentieth century and early twenty-first century. In the case of the Brazilian Northeast, tourism has gained recognition in recent decades, the fruit of the intense change in the conception of the economy and politics in the region, that is, the new forms of state action in the region that represent major changes and have been significantly important in the new direction of its economy.

This dynamic makes beach areas a prime commodity, stimulating the radical metamorphosis of the coastal landscape. With coastal tourism, together with the preceding maritime vacationing, ancient landscapes give way to new spaces. An area marked by the presence of ports and fishing villages is currently affected by the construction of new forms (tourist establishments adding to the maritime vacationing residences) along the whole coastline and causing the insertion of new actors and the expulsion of the former inhabitants, as well as, paradoxically, strengthening resistance movements (DANTAS, 2005; DANTAS; PEREIRA; PANIZZA, 2008).

Given that Brazilians were discovering the sea while transformations were occurring in the western lifestyle, at the end of the nineteenth century, Rio de Janeiro and especially Copacabana, emerged as markers of the process in the Southeast region, in view of the taste for vacationing and the influence of the nobility as the upholders of refined customs. It was also due to the arrival of the Portuguese royal family and the installation of the Court in the city of Rio de Janeiro in 1808, when effectively Brazil opened up to Europe. All these influences manifest themselves in a different

$9 \quad$ For Dantas and Pereira (2010, p. 72), "if until that moment living on the beach was a unique attribute of traditional and poor populations, established in fishing villages, the arrival of vacationers, animated by the desire to establish themselves on the beach, imposes new rationality “. 
socio-spatial form around the Brazilian territory. Coastal regions of the South ${ }^{10}$ and Southeast were the first affected, in the 1950s and 1960s. The South was strongly marked by European immigration. In general terms in the Northeast, the 1970s were a milestone. According to Moraes (1999), Dantas (2002, 2004a, 2004b, 2006), Assisi (2003), Pereira (2006, 2012), Dantas Pereira and Panizza (2008), and Dantas (2010), of the activities in the coastal zone, maritime vacationing is the one that best symbolizes and represents the expansion of the metropolitan urban fabric in the Northeast.

\section{EXPANDING THE DISCUSSIONS: NEW SCALES OF ANALYSIS}

However, it is necessary to expand the horizon of these discussions so that, taking into consideration that medium-sized cities, including Mossoró, have shown significant levels of economic and population growth, rebutting the influence of the increase in vacationing, both directly and in a number of ways, in many cities in their sphere of influence. One example is Tibau, which is a visible reflection of the economic dynamism achieved by these cities, in our case, Mossoro's growth in recent years.

The cities in question are located in the Brazilian northeast, in the State of Rio Grande do Norte, in the micro region of Mossoró, as proposed by the Brazilian Institute of Geography and Statistics (IBGE).

Currently Mossoró has almost 260,000 inhabitants. It is the second major city in the state of Rio Grande do Norte, located between the capitals of Fortaleza-CE and Natal-RN. With large area under its influence, it is among the new economically dynamic areas of Brazil. Located about 200 $\mathrm{km}$ from the capital and, according to the Brazilian Institute of Geography and Statistics (IBGE, 2008), with a catchment area of approximately 650,000 inhabitants, it consists of about forty municipalities located in the State of Rio Grande do Norte, while establishing important relationships with municipalities in other states (especially Ceará and Paraíba).

Mossoró has a fundamental role in the development of Tibau and the distinctness of its maritime vacationing. In a previous work we studied the prominence of Mossoró in its productive region (GOMES, 2007). This city has very unique characteristics in the context of other medium-sized Brazilian cities, demonstrating its growing importance and its relevant regional attribution. Due to its privileged location, the city is in the transition between the coast and the hinterland and can be reached by the federal highways BR 110, 304 and 405, as well as intermunicipal highways.

To understand Tibau it is necessary to turn to Mossoró and its history. Therefore, our analytical scale takes three possibilities into account: First, the region of Mossoró, secondly the more direct relationship between Mossoró and Tibau, and finally the city of Tibau itself

10 The arrival of European immigrants to Rio Grande do Sul in the second half of the nineteenth century introduced, through the medical class, the scientific knowledge related to the therapeutic practices spread in Europe. The immigration of a German medical class specializing in hydrotherapeutic knowledge has transferred to southern Brazil several knowledge that has spread strongly in some communities of German immigration. It was from the therapeutic baths that the initial relations of the society with the sea were given. In Brazil, the south region experienced this process strongly. Schossler (2010) discussing the origins of the vilegiatura in Rio Grande do Sul raises this question and presents a brief report on the establishment of bathing establishments and sanatoriums in this region. His study discussed the change that occurred in the social imaginary of gauchos in relation to the coast. This came to have a positive representation, with the emergence of urban-industrial society. Thus, for the author, throughout the twentieth century, the coast ended up being integrated with the imagery of the gauchos with new meanings. The beaches of Rio Grande do Sul closely resembled the European beaches of the North Atlantic and Baltic Sea, awakening since the eighteenth century the interest of curators in the treatment of various diseases. In the last quarter of the nineteenth century, the therapeutic baths in the marine waters of Rio Grande do Sul were already sought by some curators. However, it was not long before curism became hedonistic. The passage from curism to tourism, in Rio Grande do Sul, occurred as a rapid transition in the first decades of the twentieth century. The seaside resorts played an important role in the urbanization process of the northern coast of Rio Grande do Sul. From the first decades of the twentieth century, it provided material conditions for population concentration on the seafront during the three summer months. This process gradually redefined the coastal landscape of this space. 
As we discussed the expansion of the number of second homes in the cities, we began by pointing out that almost all the municipalities of Rio Grande do Norte surveyed in the IBGE Demographic Census of 1980 and 2010 ( see Table 1 below) increased the number of second homes. Most of them belong to the Metropolitan Region of Natal, except Tibau. This is the case for not only the municipalities of Rio Grande do Norte, but also in municipalities in Brazil as a whole, which have a very significant percentage of such housing. Unlike the metropolitan area, international capital has not invested in real estate in this city at the present time. To understand Tibau's differential in the reality of Rio Grande do Norte and even the Northeast, we need to understand its relationship with the relevant medium-sized city of Mossoro.

Table 1 - Distribution of the number of dwellings for occasional use in coastal municipalities. Rio Grande do Norte, 1980-2010

\begin{tabular}{|c|c|c|c|c|c|c|c|}
\hline Municipalities & $\begin{array}{c}\text { Number } \\
\text { of Second } \\
\text { Homes } \\
1980\end{array}$ & $\begin{array}{c}\text { Number } \\
\text { of Second } \\
\text { Homes } \\
1991\end{array}$ & $\begin{array}{c}\text { Number } \\
\text { of Second } \\
\text { Homes } \\
2000\end{array}$ & $\begin{array}{c}\text { Number } \\
\text { of Second } \\
\text { Homes } \\
2010\end{array}$ & $\begin{array}{c}\text { Variation } \\
1980 \text { - } 1991 \\
(\%)\end{array}$ & $\begin{array}{c}\text { Variation } \\
1991 \text { - } 2000 \\
(\%)\end{array}$ & $\begin{array}{c}\text { Variation } \\
2000-2010 \\
(\%)\end{array}$ \\
\hline Areia Branca & 41 & 234 & 294 & 1,135 & 470.7 & 25.6 & 286.1 \\
\hline Baía Formosa & 35 & 216 & 229 & 306 & 517.1 & 6 & 33.6 \\
\hline Caiçara do Norte ${ }^{1}$ & 0 & 0 & 128 & 129 & & & 0.8 \\
\hline Canguaretama & 75 & 209 & 332 & 485 & 178.7 & 58.9 & 46.1 \\
\hline Carnaubais & 7 & 59 & 258 & 223 & 742.9 & 337.3 & -13.6 \\
\hline Ceará-Mirim & 210 & 579 & 910 & 1858 & 175.7 & 57.2 & 104.2 \\
\hline Eduardo Gomes & 550 & 0 & 0 & & -100 & & \\
\hline Extremoz & 413 & 1223 & 2471 & 4354 & 196.1 & 102 & 76.2 \\
\hline Galinhos & 3 & 41 & 67 & 63 & 1266.7 & 63.4 & -6 \\
\hline Grossos & 404 & 1277 & 135 & 225 & 216.1 & -89.4 & 66.7 \\
\hline Guamaré & 0 & 19 & 213 & 341 & & 1021.1 & 60.1 \\
\hline Macau & & 161 & 476 & 785 & & 195.7 & 64.9 \\
\hline Maxaranguape & 149 & 841 & 980 & 1423 & 464.4 & 16.5 & 45.2 \\
\hline Natal & 522 & 1452 & 2780 & 5850 & 178.2 & 91.5 & 110.4 \\
\hline Nisia Floresta & 401 & 2016 & 3442 & 5674 & 402.7 & 70.7 & 64.8 \\
\hline Parnamirim & 887 & 887 & 1823 & 4018 & 0 & 105.5 & 120.4 \\
\hline Pedra Grande & 14 & 88 & 219 & 226 & 528.6 & 148.9 & 3.2 \\
\hline Porto do Mangue $^{2}$ & 0 & 0 & 34 & 214 & & & 529.4 \\
\hline São Bento do Norte & 31 & 26 & 34 & 102 & -16.1 & 30.8 & 200 \\
\hline Rio do Fogo $^{3}$ & 0 & 0 & 476 & 954 & & & 100.4 \\
\hline São Miguel de Touros ${ }^{4}$ & 0 & 0 & 131 & 229 & & & 74.8 \\
\hline Sen. Georgino Avelino & 12 & 7 & 35 & 31 & -41.7 & 400 & -11.4 \\
\hline Tibau $^{5}$ & 0 & 0 & 1394 & 2025 & & & 45.3 \\
\hline Tibau do Sul & 44 & 168 & 243 & 923 & 281.8 & 44.6 & 279.8 \\
\hline Touros & 63 & 480 & 725 & 1194 & 661.9 & 51 & 64.7 \\
\hline Vila Flor & 1 & 12 & 15 & 24 & 1100 & 25 & 60 \\
\hline Total & 3682 & 9128 & 16830 & 31266 & 147.9 & 84.4 & 85.8 \\
\hline
\end{tabular}

Source: IBGE - Census 1991 2000; Preliminary Synopsis 2010 Census

1. Municipality emancipated in 1997 from the municipality of São Bento do Norte;

2. Municipality emancipated in 1997, from the municipality of Carnaubais;

3. Municipality emancipated in 1997, from the municipality of Carnaubais;

4. Municipality emancipated in 1997, from the municipality of Carnaubais;

5. Municipality emancipated in 1995, from the municipality of Grossos.

Before examining the variable of leisure to reflect on the relationship between Mossoro and the coast, it is necessary to point out that at first this link was associated with salt production, an important product even nowadays for Mossoró's economy. In Rio Grande do Norte, salt extraction was one of the earliest economic activities.

By the mid-twentieth century, a new variable was added to boost the relations between Mossoró and "its" coast, i.e., the search for leisure, because Mossoró's urban society absorbed external influences and as a result expressed a new interest in the sea. Therefore, the maritime phenomenon was propagated in the established space, while Tibau and modern maritime practices initially emerged as a synonym for an elegant way of life for the people who lived Mossoro. 
In our view, however, the demand for Tibau, which at the time had not yet constituted itself as such, ${ }^{11}$ was initially associated with the issue of health. The space met a demand from Mossoro's wealthy class, mainly for therapeutic purposes, as stated by Doctor Francisco Pinheiro de Almeida Castro, who also went to this city with his family and friends to enjoy the location from the beginning of the twentieth century.

Moreover, in addition to therapeutic purposes, the trip to Tibau was also justified by the pursuit of leisure. In the work of Philip and Rosado (2002), as well as in many articles published in Mossoró's newspapers (especially The Mossoroense) there is evidence of this interest and consequently the frequent movement of people to the coast in search of its natural beauty and pleasant climate. This favored and the creation of a setting that was organized by the daily life of vacationers on this beach.

Thus, we credit Mossoro with the current form of Tibau. It is precisely the regional context and the socioeconomic relevance of Mossoró that have favored Tibau's current socio-spatial organization. As a medium-sized city, Mossoró plays an important role in its urban network, centralizing various functions. Fruit of the new Brazilian urban and economic dynamic, it has a considerable degree of relevance in the network of the cities to which it belongs. Such is its dynamism that in recent years it has imposed new uses on the coastal area of some cities under its influence, the most important of these being Tibau. We argue that several municipalities can be identified in Brazil whose urbanization is directly attributable to the expansion of coastal tourism and maritime vacationing and whose main function is clearly associated with the demands of these elements; it is clear that Tibau fits this logic exactly.

In Tibau there is a spatial morphology that is intrinsic to the social phenomenon of modern maritimity, such as agglomerations of second homes and urban subdivisions near the sea. In this location, maritime vacationing materializes territories intended mainly for the population of Mossoró Figures 2, 3, 4 and 5). It is the intense relationship between Tibau and Mossoró, the second most important city in the state, which shapes the territories of maritime vacationing.

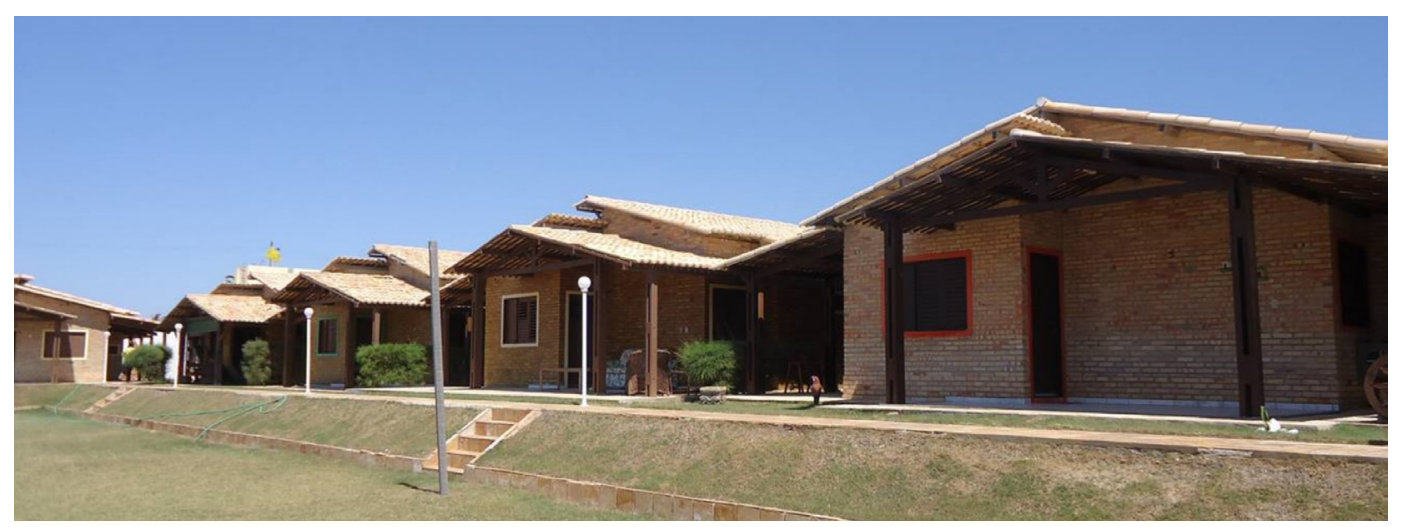

Figura 2 - Figure 2 - Horizontal condominium in Tibau, RN Author: Iara Rafaela Gomes

Maritime vacationing in Tibau was the first modern maritime practice to drive the spread of the urban and its consequences, related both to spatial forms and to the recent social conditions established in these spaces.

11 Mossoró, until 1892 was a coastal municipality. It was only this year that the district of Areia Branca disembed from Mossoró and was elevated to the condition of municipality. On December 11, 1953, Grossos disembarked from Areia Branca, becoming a municipality, and only on November 21, 1995 Tibau was dismembered from Grossos and also became a municipality of Rio Grande do Norte. (IDEMA, 2008). 

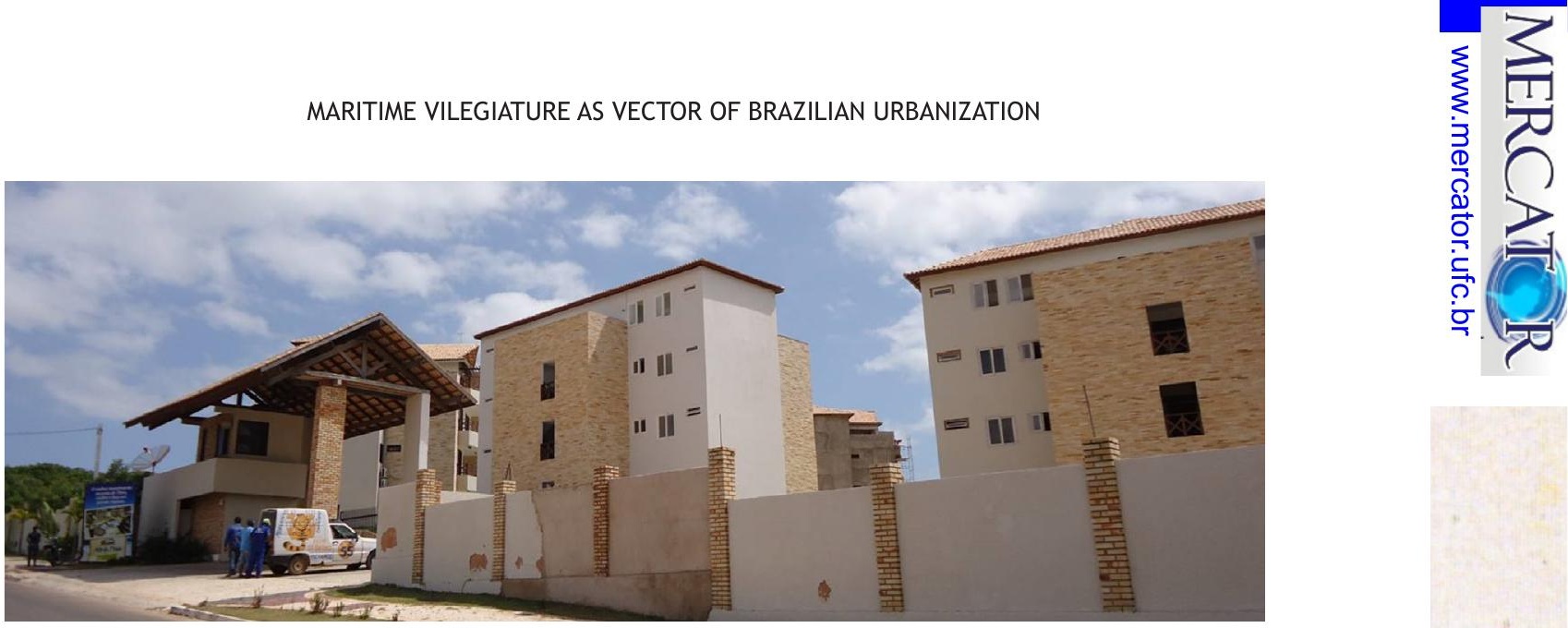

Figure 3 - Vertical condominium in Tibau-RN Author: Iara Rafaela Gomes

Secondary residences materialize this process and it is through their use that vacationers expand their living spaces because even if this activity involves the opportunities for many leisure pursuits, the practice of vacationing certainly involves the sense of habitation and all its ties. For this reason, amid those expounded above, we consider it quite relevant to discuss the relationship between the spread of the modern maritime practice of maritime vacationing and its relations with the urbanization process. We also highlight our interest in studying the processes that occur beyond the metropolitan scale.

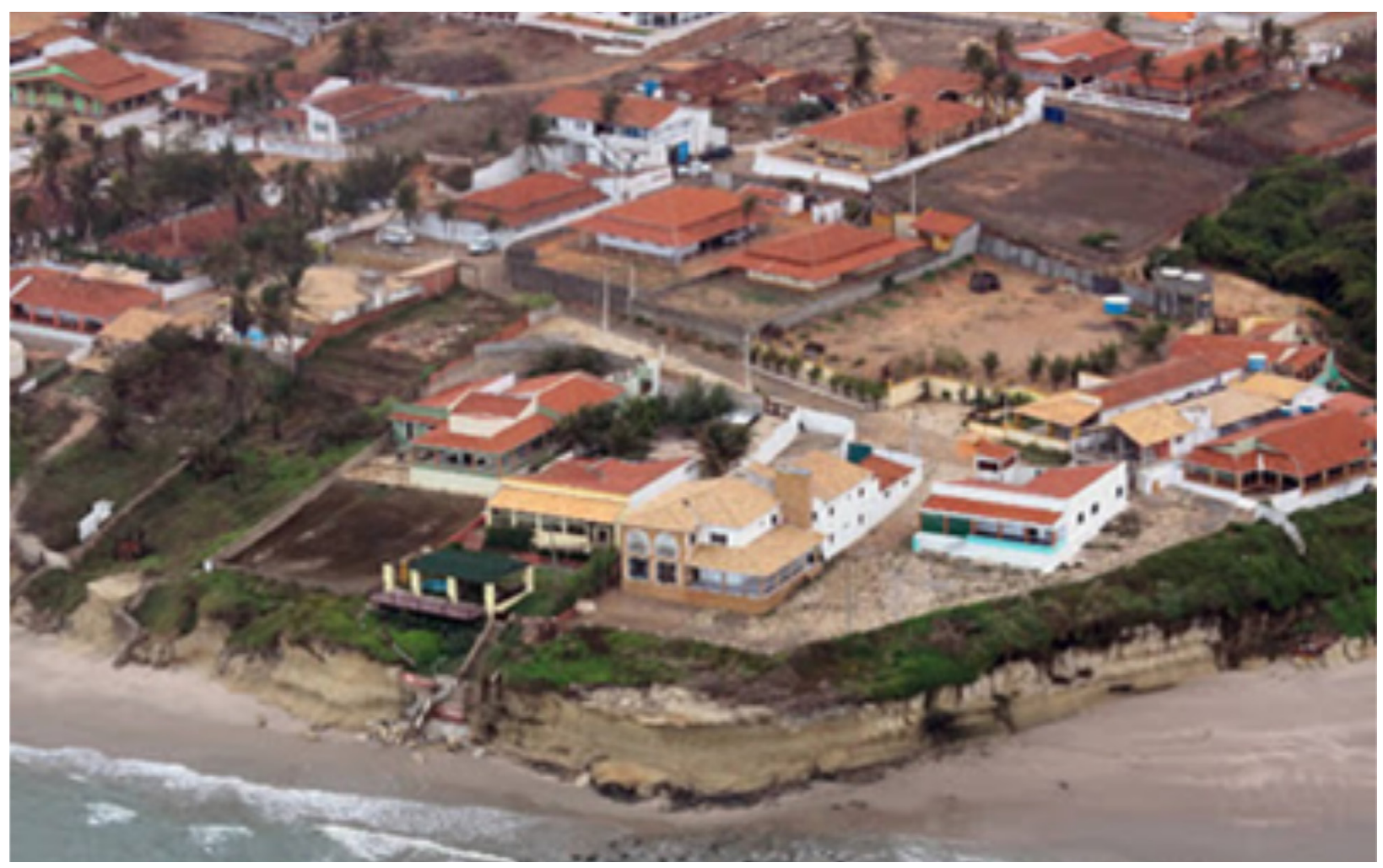

Figure 4 - Homogeneous cluster in Tibau-RN Source: http://www.tibau.blogspot.com.br/p/tibau.html (Accessed June 12, 2012). Author: Raul Pereira.

The value of coastal areas and especially modern maritime vacationing practice are understood to be historically constituted social processes, raising the sea and the maritime to elements included in the daily life of urban society. From this perspective, beaches acquire new symbology and move 
from being a "frightening and dirty" place to the place for leisure, giving them the ability to cause in people, particularly those living in urban areas, the desire to consume the coastal space.

The dynamic experienced by Tibau in recent years denotes very well the leisure society that has appropriated the city's beach, establishing a strong territorial link with the place, conceiving the essential factors of comfort and convenience imposed by urban society. In this way, it is their socio-spatial practices that directly affect the spatial organization of Tibau, that is, the city's urbanization process.

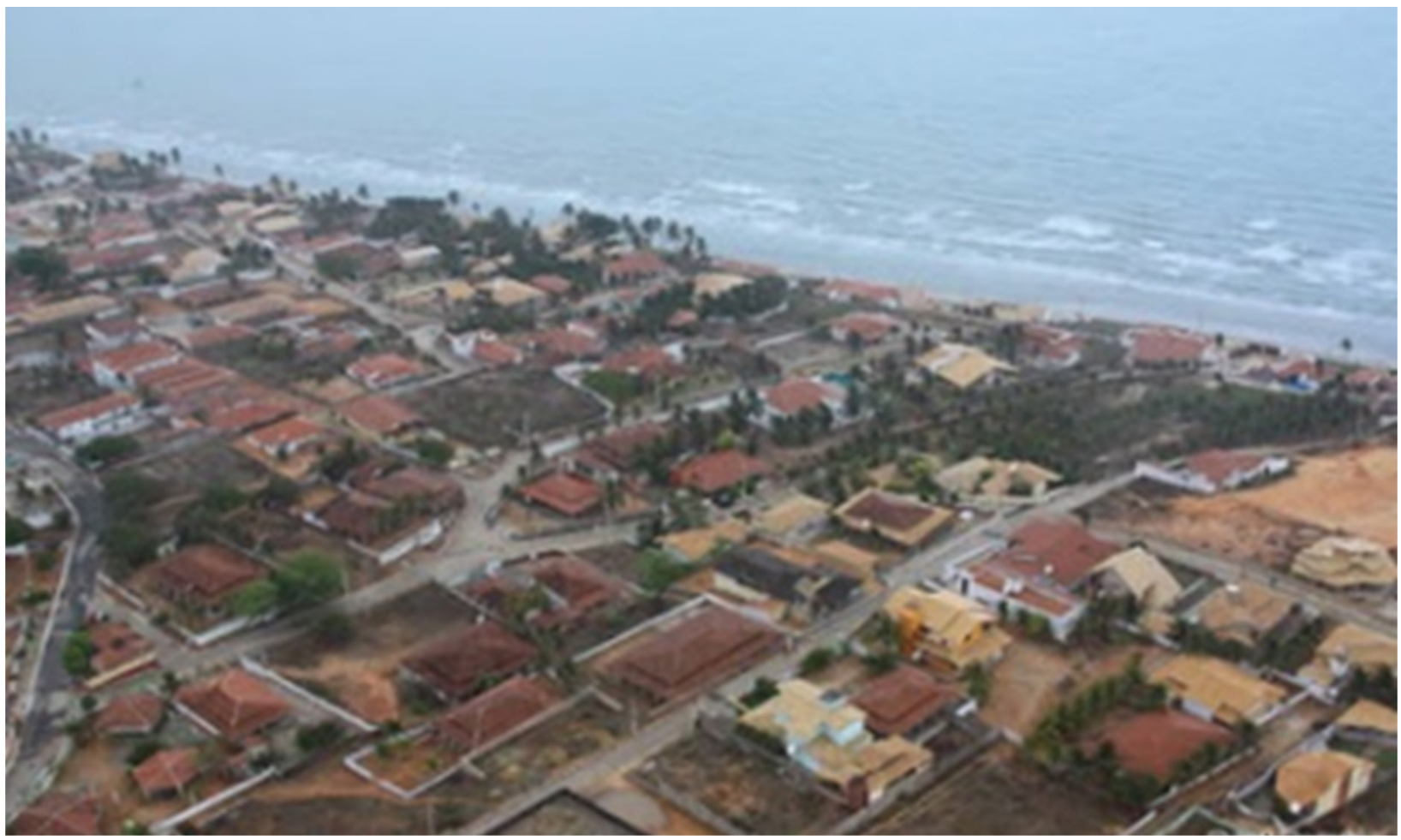

Figure 5 - Heterogeneous cluster in Tibau-RN

Source: http://www.tibau.blogspot.com.br/p/tibau.html (Accessed June 12, 2012). (Accessed June 12, 2012). Author: Raul Pereira.

In the organization of Tibau's coastal space, there is a clash of temporalities that recreates forms and assigns them a new essence. This is relevant to understand the changes in this coastal area, as the social agents involved in the process have been redefined, over a few decades.

Nevertheless, despite its redefinition, it is Mossoro's influence on the materialization of maritime vacationing in Tibau that has demonstrated how the urban fabric reaches the coastal space, showing in this way the dialectical relationship between the increased value of the coast, maritime vacationing and urbanization.

\section{FINAL CONSIDERATIONS}

The aim of this study was to demonstrate how in the current historical period the complex process of urbanization has occurred from different vectors and that in a country like Brazil, with continental dimensions and an immense coastline, there is an even broader phenomenon, due to new urbanization trends, leading us to reflect on the new vectors that are shaping the country.

In our view, one way of recognizing Brazilian society and territory is the study of the maritime vacationing that has taken place in the last decades as a way of approaching the new trends of urbanization in Brazil. 
We took as our object the city of Tibau, in Rio Grande do Norte, and its remarkable relationship with Mossoró. Therefore, it is still important to know that the history of this city and its relationship with the coast was initially totally linked to salt production, which is an important product for Mossoró's economy even today.

In Rio Grande do Norte, salt extraction was one of the first economic activities. According to Souto and Fernandes (2005), artisanal and extensive exploration of Mossoro's salt flats and the coast of the municipalities of Areia Branca, Açu and Macau, dates from 1802, but the discovery of natural deposits in the region occurred from the beginning of colonization. For Felipe Lacerda (1988), Mossoro's economy has always been linked to salt production, because it was evident even in the last century that there was a relationship between the dried-meat producers and the salt deposited naturally by the tides in the shallows and hollows of the floodplains at the mouth of the Mossoró River.

However, in our times, the relationship established between Mossoró and the coastal areas of Tibau is based on a new variable, whether for leisure or for its decisive role in this coastal area even before the regional tourism planning policies. We understand this variable through the relationship between maritime vacationing and second homes. Along with the increase of coastal tourism, these have contributed to the spread of urban structures in the coastal area of the Northeast and in particular of Rio Grande do Norte and some of its coastal cities throughout the twentieth century.

To analyze one of the cities that most represents this logic, Tibau in Rio Grande do Norte, some variables should be highlighted to indicate the expansion of the urbanization process and the influence of maritime vacationing on the latest changes, which contribute to strengthen the emphasis on the aforementioned process. It is interesting to note that the choice of a breakdown at the local level provides additional views of the phenomenon, because we can recognize both characteristics and profiles similar to those found in the literature on other Brazilian and Northeastern cities. The study of Tibau, that is, this local research, allows an analysis from new research sources, such as fieldwork, cooperating in the development of methodological possibilities to analyze maritime vacationing in the tropics.

The variables analyzed in this research helped to understand the process of urbanization in Tibau using maritime vacationing. Batista $(2012$, p. 185) published a study showing this process, pointing to the existence of a territory in the city, with several territorialities, that "subverts community life." This author denounces the difficult governance by the municipal authorities and the lack of an "explicit" political project, causing disordered actions.

In our research, we chose studies that show the strength of current small and medium-sized cities, given the dynamism experienced by the urbanization process in Brazil in recent years, including many vectors that drive it and new trends that this process has been indicating. Therefore, the study of small and medium-sized cities deserves a special reflection, but without losing sight of the notion of the totality of the urban phenomenon.

In this line of approach, one issue emerges as being fundamental because of the inclusion of maritime vacationing in studies on urbanization as an important intensifying vector of the said process.

\section{BIBLIOGRAPHIC REFERENCES}

ALEDO, A. Turismo y desarrollo: una reflexión sobre las teorías del post-desarrollo. Antonio Miguel Nogués (ed.) Cultura y turismo. Sevilla, Signatura Demos, 2004.

ALEDO, A. Los otros inmigrantes: residentes europeos en el sudeste español, en J. Fernández Rufete y Modesto García (eds.) Movimientos migratorios europeos. Murcia, UCAM, 2005.

ALEDO, A y MAZON, T. El Bajo Segura: Análisis Turístico. Alicante, Diputación de Alicante, 1997. 
ARROCHA, A. La hacienda local en los destinos turísticos: el caso de Torrevieja, in: T. Mazón y A. Aledo, Turismo residencial y cambio social. Alicante, CAM-UA, 2005.

ASSIS, L. F. de. Turismo de segunda residência: a expressão espacial do fenômeno e as possibilidades de sua análise geográfica. Revista Território, Rio de Janeiro, ano 7, n. 11-13, p. 107-122, set./out. 2003.

BATISTA, J. L. D. V. Vilegiatura marítima e urbanização em Tibau. In: FONSECA, M. A. P. da (Org.). Segunda residência, lazer e turismo. Natal: EDUFRN, 2012.

BATISTA, J. L. D. V.; OLIVEIRA, E. J. de. Vilegiatura marítima e urbanização em Tibau. In: IX Seminário da Associação Nacional Pesquisa e Pós-Graduação em Turismo. Universidade Anhembi Morumbi. São Paulo, 2012.

BRITO, S. P. Imobiliária do Lazer e Turismo Residencial. SPI - Sociedade Portuguesa de Inovação, 2010. COLÁS, J. L. La residencia secundaria en España. Tesis doctoral. Departament de Geografia. Faculdat de Filosofia i Lletres. Universitat Autônoma de Barcelona. 440 f. Barcelona, 2003.

CORBIN, Alain. O território do vazio. São Paulo: Companhia das Letras, 1989.

COUTO, E. M. J. Redefinições espaciais do comércio em Mossoró (RN). Dissertação. (Mestrado em Geografia) - Pós-Graduação em Geografia da Universidade Estadual do Ceará - UECE, Fortaleza, 2011.

DANTAS, E. W. C. Mar à vista. 2. ed. Fortaleza: UFC, 2011.

DANTAS, E. W. C. Maritimidade nos trópicos. 2. ed. Fortaleza: Edições UFC, 2010a.

DANTAS, E. W. C. Mutações no Nordeste brasileiro. Confins, Paris, v. 10, p. 1-20, 2010b.

DANTAS, E. W. C. Imaginário social nordestino e políticas de desenvolvimento do turismo no Nordeste brasileiro. GEOUSP, v. 22, p. 9-30, 2007.

DANTAS, E. W. C. Rede urbana colonial cearense. Revista do Instituto do Ceará, v. 120, p. 145-170, 2006 a. DANTAS, E. W. C. Cidades litorâneas marítimas tropicais. In: SILVA, J. B.; LIMA, L. C.; DANTAS, E. W. C.(Org.). Panorama da geografia brasileira 2. São Paulo: Annablume, 2006b. v. 1, p. 79-89.

DANTAS, E. W. C. O mar e o marítimo nos trópicos. GEOUSP, São Paulo, v. 15, n. 1, p. 63-76, 2004a.

DANTAS, E. W. C. Maritimidade nos trópicos. Revista da Sociedade Cearense de Geografia e História, Fortaleza, v. 1, p. 23-29, 2004b.

DANTAS, E. W. C. Construção da imagem turística de Fortaleza/Ceará. Mercator, Fortaleza, v.1, p. 53-60, 2002.

DANTAS, E. W. C. Da capital do sertão à cidade do sol: Fortaleza e o processo de litoralização do Ceará. Caderno de Geografia: notas sobre o urbano cearense, Fortaleza, v. 4, 1998.

DANTAS, E. W. C.; FERREIRA, A. L.; LIVRAMENTO, M. C.(Org.). Turismo e imobiliário nas metrópoles. Rio de Janeiro: Letra Capital, 2010.

DANTAS, E. W. C.; PEREIRA, A. Q. Reflexões sobre a vilegiatura marítima nos trópicos. In: DANTAS, E. W. C; FERREIRA, A. L; CLEMENTINO, M. L. M. (Org.). Turismo e imobiliário nas metrópoles. Rio de Janeiro: Letra Capital, 2010. v. 1, p. 71-84.

DANTAS, E. W. C. et al. Turismo Litorâneo e Vilegiatura Marítima na Região Metropolitana de Fortaleza. In: 12 ENCUENTRO DE GEÓGRAFOS DE AMÉRICA LATINA, 2009, Montevideo. Caminando en una América Latina en transformación, 2009. v. 1. p. 1-15.

DANTAS, E. W. C.; PEREIRA, A. Q.; PANIZA, A. Urbanização litorânea e vilegiatura marítima nas metrópoles nordestinas brasileiras. Cidades, Presidente Prudente, v. 5, p. 14-34, 2008.

DANTAS, E. W. C.; SILVA, J. B.; CAVALCANTE, T. C. (Org.). Ceará. Fortaleza: Demócrito Rocha, 2007. DANTAS, G. A. F. A formação das representações sobre a cidade colonial no Brasil. Tese (Doutorado em Arquitetura e Urbanismo) - Programa de Pós-Graduação em Arquitetura e Urbanismo da Escola de Engenharia de São Carlos da Universidade de São Paulo, São Carlos, 2009.

DELGADO, C. Vivienda secundaria y turismo residencial como agentes de urbanización y segregación territorial en Cantabria. Scripta Nova - Revista Electrónica de Geografía y Ciencias sociales. Barcelona: Universidad de Barcelona, 15 de julio de 2008, vol. XII, núm. 261. Disponível em: . [ISSN: 1138-9788].

FELIPE, J. L. A. Mossoró: um espaço em questão. Mossoró: Fundação Guimarães Duque, 1980. 
FELIPE, J. L. A. Organização do espaço urbano de Mossoró. Mossoró: Fundação Guimarães Duque, 1982. FELIPE, J. L. A. Elementos de geografia do Rio Grande do Norte. Natal: EDUFRN, 1988.

FELIPE, J. L. A. Rio Grande do Norte: uma leitura geográfica. Natal, RN: EDUFRN, 2010.

GOMES, I. R. Vilegiatura além da metrópole: urbanização em Tibau (RN). Tese (Doutorado) - Universidade Federal do Ceará, Centro de Ciências, Programa de Pós-Graduação em Geografia, Fortaleza, 2013. IBGE. Atlas geográfico das zonas costeiras e oceânicas do Brasil. Rio de janeiro, 2011.

IBGE. Censo demográfico 2000. Rio de Janeiro, 2000.

IBGE. Censo demográfico 2010. Rio de Janeiro, 2010.

PEREIRA, A. Q. A urbanização vai à praia. Tese (Doutorado em Geografia) - Universidade Federal do Ceará, Centro de Ciências, Departamento de Geografia, Pós-Graduação em Geografia, Fortaleza, 2012.

PEREIRA, A. Q. A urbanização vai à praia. 1. ed. Fortaleza: Edições UFC, 2014. 202p .

PEREIRA, A. Q. Veraneio marítimo e expansão metropolitana no Ceará. 2006. 157 f. Dissertação. (Mestrado em Geografia) - Pós-Graduação em Geografia da Universidade Federal do Ceará, Fortaleza, 2006.

PEREIRA, A. Q. Estruturação urbana litorânea da Região Metropolitana de Fortaleza. Mercator, v. 8, p. 49-57, 2009.

PEREIRA, A. Q. Praia do Presídio:santuário da vilegiatura. Ateliê geográfico (UFG), v. 3, p.92-110, 2009 b.

PEREIRA, A. Q. Das cidades às metrópoles litorâneas. GEOUSP, v. 31, p. 5-15, 2012.

HALL, C. M.; MÜLLER, D. R. Introduction: second homes, curse or blessing? Revisited. In: . (Orgs.). Tourism, mobility and second homes. Clevedon (UK): Channed View Publications, 2004. p. 3-14.

HIERNAUX-NICOLAS, D. La promoción inmobiliaria y el turismo residencial: el caso mexicano. Scripta Nova, Universidad de Barcelona, v. IX, n. 194 05, 1 agosto 2005.

PEREIRA, A. Q.; DANTAS, E. W. C. Veraneio marítimo na metrópole: o caso de Aquiraz, Ceará-Brasil. Sociedade \& Natureza, v. 20, p. 1-12, 2008.

MORAES, A. C. R. Classificação das praias brasileiras por níveis de ocupação. In: BRASIL. Ministério do Meio Ambiente; Ministério do Planejamento. Projeto Orla. Brasília, 2004. p. 33-44.

MORAES, A. C. R. Bases da formação territorial do Brasil. São Paulo: Hucitec, 2000.

MORAES, A. C. R. Contribuições para a gestão da zona costeira do Brasil. São Paulo: HUCITEC, 1999. NIEVES, R. H.; TERÁN, A. M.; MARTÍNEZ, T. M. ¿De qué hablamos cuando hablamos de turismo residencial? Cuadernos de Turismo, n. 22, 2008, p. 101-121.

ROQUE, M. L. Contribuição para o estudo da origem e do desenvolvimento da função balneária da ilha de Santo Amaro antes do "boom” imobiliário. 1990. Tese - Universidade de São Paulo. São Paulo, 1990. SANTOS, M.; SILVEIRA, M. L. O Brasil. Rio de Janeiro: BestBolso, 2011.

SANTOS, M. Urbanização brasileira. São Paulo: HUCITEC, 1993. 173 p.

SCHOSSLER, J. C.. "As nossas praias": os primórdios da vilegiatura marítima no Rio Grande do Sul. (1900 - 1950). 2010. Dissertação (Mestrado em História) - Pontifícia Universidade Católica do Rio Grande do Sul, Programa de Pós-Graduação em História da Faculdade de Filosofia e Ciências Humanas. Porto

Alegre, 2010.

SEABRA, O. C. L. A muralha que cerca o mar. Dissertação (Mestrado em Geografia) - Faculdade de Filosofia, Letras e Ciências Humanas, São Paulo, 1979.

SILVEIRA, B. R.. O morar permanente na praia. 2011. Dissertação. (Mestrado em Geografia - Programa de Pós-Graduação em Geografia, Fortaleza, 2011.

SOARES JUNIOR. A. T. P. A espacialidade do vilegiaturista marítimo em Fortaleza-CE. 2010. Dissertação (Mestrado em Geografia) - Centro de Ciências. Programa de Pós-Graduação em Geografia. Universidade Federal do Ceará, Fortaleza, 2010.

SOUTO, E. F.; FERNANDES, C. H. C. A importância da indústria salineira do Rio Grande do Norte para a economia brasileira. Mossoró: Coleção Mossoroense, 2005. 
SPOSITO, M. E. B.; ELIAS, D. Cidades médias brasileiras. Projeto de pesquisa. Fortaleza, 2006.

TULIK, O. Residências secundárias. 1995. 154 f. Tese (Livre Docência) - Escola de Comunicações e Artes, Universidade de São Paulo. São Paulo, 1995.

TULIK, O. Turismo e meios de hospedagem. São Paulo: Roca, 2001. 